УДК:069.5:929(477.411):94(100)“1939/1945”

DOI: 10.33099/2707-1383-2020-38-4-220-230

Янковенко О.О., головний зберігач,

Національний музей історії Украӥни

у Другій світовій війні.

Меморіальний комплекс (м. Київ, Україна)

ORCID: https://orcid.org/0000-0002-7372-8903

Третяк В.Л., кандидат історичних наук, завідувач відділу науково-фондової роботи, Національний музей історії України

у Другій світовій війні.

Меморіальний комплекс (м. Київ, Украӥна)

ORCID: https://orcid.org/0000-0002-4324-4545

\title{
ФОНДОВЕ МУЗЕЙНЕ ЗІБРАННЯ ЯК ЗАПОРУКА ВІЗУАЛІЗАЦІЇ НАРАТИВУ ДРУГОЇ СВІТОВОЇ ВІЙНИ
}

У розвідиі відрефлексовано фондове зібрання Національного музею історії України у Другій світовій війні. Меморіальний комплекс як підгрунтя до організації експозитарного простору за відповідною проблемною палітрою, акиентні етапи його комплектування відповідно до трансформації візійного поля, теоретичних та методологічних конструктів у означеній царині. Окрім того, колекиію Музею розглянуто як потенційний джерельний масив для укладання модерної моделі української історії Другої світової війни, ї̈ ефективної артефактної візуалізації в музейних інституціях.

Ключові слова: Національний музей історії Украӥни у Другій світовій війні. Меморіальний комплекс, фондове зібрання, експозиція, джерело, візуалізація, Друга світова війна, Україна.

В умовах сучасних викликів, що постали перед нашою країною, в часи випробувань державницького гарту засадничою є проблема ретельного плекання цілісної, акцентно національної модерної візії історичного поступу, з дальшою іiї інкорпорацією в суспільство. Це дасть змогу віднайти орієнтири на цивілізаційному роздоріжжі, де наразі перебувають українці. Украй потрібний для стимулювання процесу самовизначення та ідентичності мисленнєвий продукт уможливлює глибинне рефлексування минулого науковими елітами у просторі дискусії та консенсусу, спільно з провідними інституціями - акумуляторами знань (історичних, політологічних, філо-

софських, правничих тощо), а також методологічного й джерельного наративу. Не менш важливим видається й витворення оптимальних (доступність, дієвість тощо) форм візуалізації цих інтелектуальних пошуків.

Насамперед віднаходження адекватних теоретичних конструктів та їх артефактно унаочненої ретрансляції музейними інституціями потребує історичний спадок, що має резонанс та екстраполяцію у вітчизняному соціумі. Звісно, в цьому дискурсі варто акцентувати на питаннях Другої світової війни. У представленій розвідці спробуємо зробити це на основі фондового зібрання Національного музею історії України 
у Другій світовій війні. Меморіальний комплекс.

Довгий час усталена радянським літописанням і вмурована тотальною пропагандою в суспільну свідомість війна поставала у вигляді монументального полотна (виключно двоколірного, безособово-колективного, національно унітарного, лінійного, переважно баталістичного, гіперглорифікованого) й була трактована як головний вододіл в історії «Країни Рад». Ця стала міфологема, що мала передусім забезпечити життєздатність кремлівського режиму, десятиліттями визначала світосприймання та самоідентифікацію цілих поколінь українців, водночас табуюючи їхню пам'ять щодо попереднього, «довоєнного» буття. Нині ці «наукові» напрацювання $\epsilon$ апологетикою інформаційного простору у віковій війні Москви проти українства та його державності, а напрацьований радянською імперією інструментарій силової боротьби широко використовується для окупації українських земель.

Своєю чергою українці - бездержавна нація, носії різних моделей ідентичності, роздерті ментально, культурно, духовно, географічно, складові відмінних за суттю й змістом державних форм та політичних режимів, змушені до осібного морального вибору й побудови ціннісної системи координат у відверто протилюдяному просторі глобального катаклізму, яким була Друга світова війна, - торували окремі стежини. Спільне між ними, і то доволі умовно, можна окреслити такими загальними категоріями, як «людина зі зброєю» та «людина без зброї», де кожен також визначав власне місце.

Означений вище стан речей надалі призвів до появи в українському середовищі багатосегментного пам'яттєвого пазлу. Щоб скласти його докупи, необхідно, на наш погляд, відійти від хронологічно-поді- євого висвітлення тих подій, узявши за основу проблемні студії та репрезентувавши їх як плетиво різноштибних причинно-призвідних, похідно-супровідних та інерційно-наслідкових макро- й мікропроцесів.

Такі методологічні підходи вже інтегровано до науково-експозитарної практики Національного музею історії України у Другій світовій війні. Меморіальний комплекс - однієї з провідних вітчизняних інституцій, що наративують, рефлексують i репрезентують на широкий загал проблемну палітру найбільшого в історії людинотворного апокаліпсису.

Грунтовно унаочнити чи принаймні фрагментно окреслити великий обсяг питань і процесів вітчизняної воєнної історії в музейному просторі має його зібрання, що до того ж $є$ потенційним джерельним пластом та одним із опірних майданчиків для укладання модерної візії української Другої світової війни. Наразі основу колекції становлять близько 400 тис. артефактів. Водночас безперервним є динамічний, гнучкий, чутливий, живий процес наукового комплектування фондозбірні Музею.

Музейне уфондування було започатковано ще на зламі гарячої, чи то пак збройної стадії Другої світової війни у 1943-1944 pp. ${ }^{1}$ [15]. Однак, зважаючи на тогочасну історичну дійсність, відповідно до політичної кон'юнктури, в лещатах тоталітарного світобачення, всеохопної пропаганди, повсюдної цензури та жорсткої та буйованості, через труднощі, пов'язані

\footnotetext{
${ }^{1}$ Мається на увазі те, що Друга світова війна пройшла кілька стадій. Холодна - була позначена сукупністю процесів, що призвели до зародження майбутнього конфлікту й наростання у версальській політико-економічній кухні максимального градуса напруження. Наступна стадія - гаряча — вилилась у глобальне бойовище, докорінну руйнацію попереднього світоустрою, перехід до умовного постверсальського, ялтинського повоєння.
} 
з бюрократією, регульованою вручну системою зі складною дозвільною архітектонікою, сповненою численних важелів стримування й контролю, артефактне зібрання набуло конкретно-темарійної спрямованості й ідеологічної рельєфності. Та це не завадило закласти тверду основу для однієї 3 наймасштабніших музейних платформ із відповідним спрямуванням.

Цінність колекції тієї доби полягає передусім у тому, що зібрано іiі було безпосередньо під час війни або ж у наближений до неї період. Хоча це переважно радянський джерельний масив, за нинішньої конотації він дає змогу різнопланово поглянути на широкий спектр воєнних граней, зокрема стосовно радянських мобілізаційних заходів, щодо питань статусу військовополонених та механізму функціонування штрафних частин, на реалії окупаційного повсякдення, український визвольний рух, дивізійництво, різноштибні українські військові та поліційні допоміжні формації тощо.

Iз відновленням суб'єктного статусу України в музейній практиці у взаємодії 3 академічною наукою розпочався доволі затяжний та складний процес деконструкції радянських парадигм і пошуку нового, власне українського, історичного поступу, що нагально потребував повної концептуальної, методологічної та джерельної верифікації.

У таких умовах у пригоді музейникам стало те, що підмурок фондового зібрання формують матеріали переважно особового походження: спогади, щоденники, приватне листування, біограми, нотатки, власноруч акумульовані пошуковцями архіви (зокрема, зібрання Івана Свдокимова — стосовно подій та людських доль у горнилі бойовища за Київ 1941 р., Володимира Литвинова яке містить розмаїту палітру життєписів остарбайтерів, Сергія Смірнова — яке від- творює фатумне існування радянських військовополонених) та ін. [10].

Рельєфну мозаїку з особистісних рефлексій, світоглядів, ціннісних вимірів безпосередніх учасників подій витворюють, попри цензуру та самоцензуру, близько 9 тис. листів. Особливим надбанням є 1215 епістол радянських військовослужбовців, датованих червнем - липнем 1941 р. Вивезені гітлерівцями 3 м. Кам'янець-Подільський, переважно в недоторканому вигляді майже 70 років вони зберігались у фондах Технічного музею Відня (Австрія) і надійшли до Музею в межах міжнародних реституційних процесів 2009 р. Відтоді колекція «ожила» й «запрацювала». На іiі базі було зреалізовано низку виставкових проектів в Україні та за іiі межами, вийшло друком музейне науково-документальне видання [8]. I головне - було започатковано соціально-гуманітарну програму «Увага! Пошук! Непрочитані листи 1941-го!», основним завданням якої став розшук рідних адресантів та адресатів. Завдяки зусиллям музейників із активним залученням місцевих органів влади, журналістів та пошуковців історія цього епістолярію дістала широкий резонанс. Нині вдалося віднайти і вручити копії листів 670 сім'ям у Свропі, Азії, Америці й одночасно уфондувати Національний музей родинною автентикою.

Від 2006 р. Музей став місцем убезпечення та наукового опрацювання унікального зібрання загальнодержавного значення - Документального фонду з обліку людських військових втрат України у Другій світовій війні, що налічує понад 10 тис. архівних справ на 3 млн військовослужбовців, які були призвані до Червоної армії 3 теренів України й загинули або зникли безвісти під час воєнного лихоліття. Нині створено й презентовано Всеукраїнську електронну базу даних «Музей. Пам'ять. Пошук», що містить 394563 записи, 
473361 сканографію і продовжує активно наповнюватися [7]. На основі цих документальних стосів здійснюються віднайдення максимально об'єктивних даних щодо загиблих у боях українців, дослідження проблеми з обліку втрат у радянських військах, робота з пошуку інформації на звернення та запити.

Значущими для музейної практики є й інші атрактивні соціогуманітарні проекти, як-от: «Родинна пам'ять про війну», «ПортретиUA» та ін. Вони є засобом для темарійного комплектування фондів особовими матеріалами, проблемними студіями, форматом артефактної репрезентації різнопланових вимірів існування українців в умовах воєнного часу.

Такий вагомий масив персональної автентики в докорінно новому експозитарному просторі Музею дав змогу закцентувати головно на гуманістичному вимірі у війні, олюднити масштабне воєнне полотно, значно поглибити й наповнити її проблемний контент, а самій музейній інституції допоміг розвиватися не як майданчику для «воєнного екстазу», «переможного оспівування», політичної пропаганди та піару, а піти шляхом поетапної трансформації передусім як місця для травматичної історії, а також індивідуальної та корпоративної комеморації [6].

Експозиціонування розлогого пласту офіційної документації уможливила співпраця 3 архівними установами, зокрема Центральним державним архівом вищих органів влади та управління України, Центральним державним архівом громадських об'єднань України, Галузевими державними архівами Служби безпеки України та Служби зовнішньої розвідки України, багатьма іншими. А завдяки тісній співдії 3 колекціонерами Музей має змогу репрезентувати в музейному просторі різні сторони протистояння. Зокрема, вельми ціка- вою є вагома добірка 3 понад 900 світлин, зроблених гітлерівцями на українських теренах. Вони фіксують відносно незатабуйовані й незаретушовані нацистською та радянською пропагандою події, хронікують фронтовий, адміністративний, соціальний, культурний побут окупантів, реалії існування українських земель в умовах воєнного лихоліття.

Загалом закумульована в цей час колекція, а також дальше проблемно спрямоване комплектування фондів послугували за основу поступового заповнення в експозиції темарійних лакун, реалізації цілого шерегу виставкових проектів, підготовки низки наукових, науково-методичних та науково-популярних видань, уведення до широкого обігу нових джерельних пластів у царині частково або повністю табуйованої радянським історієписанням палітри соціально-побутового життєплину українців в умовах різноштибних диктатур та збройних катаклізмів. Зокрема, тодішній музейний наратив таргетував такі питання, як жертви окупаційних режимів, методи та інструментарій їх упокорення, асиміляції чи винищення; організатори, виконавці, офіри та рятівники в горнилі етноцидів; різнобарвний калейдоскоп доль військових бранців та остарбайтерів; зрештою, шокуючий український демографічний та матеріальний рахунок у війні $[3 ; 4 ; 5 ; 13 ; 14]$.

Звісно, весь спектр проблемного поля Другої світової тоді вимагав ретельних наукових студій і модерного звучання, позбавленого радянського ідеологічно-пропагандистського спадку та політичного диригентства. Однак цілковито нове місце у вітчизняній історичній концепції цього мілітарного протистояння належало визначити передусім для українського визвольного руху, упродовж десятиліть свідомо скомпрометованого, затаврованого, спотвореного в пам'яттєвому вимірі більшості 
наших земляків, а також фактично викорененого з дискурсу українського минулого.

Так, у відносно невеликий термін власне на теренах нашої держави, адже такі дослідження вже доволі довгий час велися в українських емігрантських колах, завдяки спільним активним рефлексіям науковців, музейників, архівістів, краєзнавців, інших пошуковців стало можливим витворення хоч і нерельєфної, до межі невіднайденої, термінологічно несформульованої, багатоголосної, дискутивної, але україноорієнтованої візії історії оформлення та збройної боротьби українського націоналістичного підпілля й повстанства другої чверті XX ст.

Своєю чергою тогочасна специфіка музейного зібрання з окреслених вище причин не давала змоги повноцінно джерельно-артефактно унаочнити цей акцентно український сегмент вітчизняної воєнної історії. Тож майже одразу після реставрації української державності - у співпраці 3 провідними науковцями в окресленій царині та архівними установами - музейна команда розпочала сфокусовану артефактну акумуляцію i, як результат, на широкий загал репрезентувала відповідний темарійний кейс [11]. Його контент характеризував ідеологію, структуру та національний склад українських самостійницьких сил, стратегію, тактику й методи підпільно-партизанської боротьби повстанців, висвітлював iз принципово нових ракурсів постаті провідних діячів ОУН і вищої командної ланки УПА та ін. Перлинами колекції, пов'язаної з проблемою українського резистансу, можна вважати передані Галузевим державним архівом Служби безпеки України автентичні матеріали знаного художника-графіка, головного пропагандиста УПА Ніла Хасевича, а саме серії дереворитів, «бофонів», різнопланову документацію, анотовані рукою митця, вилучені 3 місця його знищення радянськими органами держбезпеки та залучені до його «справи» як «речові докази». Не меншу цікавість становить і колишній діловодний архів одного $з$ провідників ОУН на Волині Андрія Михалевича, що надійшов до фондозбірні Музею у 2010 р. Після того як цей значний джерельний масив із середовища українського підпілля надзусиллями музейних реставраторів був дивом урятований, його широко залучено до науково-експозитарної практики [2; 12].

Після чергового розв'язання Росією багатовимірної - зокрема й у сенсі «війни історій» - агресії проти українства та його національних державних інституцій перед вітчизняною спільнотою руба постало питання остаточного цивілізаційного самовизначення. Його вирішення полягає у віднайденні та інтегруванні в суспільство осібно української цілісної картини минулого. За таких умов своєрідний мікст у вітчизняному конструкті Другої світової, який складається 3 хоч і значно проблемно поглибленої, однак інерційної, хронологічно-подієвої, глорифіковано-віктимної радянської рецепції, а також національного компонента війни, українського визвольного руху, має послугувати лише відправним майданчиком для кардинально нової візії тих подій.

На наш погляд, україноорієнтоване історієписання має грунтуватися на таких проблемних дефініціях, як суб'єктність / об'єктність, і на пов'язаних із ними процесах, що своєю чергою дає змогу визначити роль і місце України та українців у історичній віхолі й навпаки. Відтак має відбутись і зміна акцентів - не віднайдення правди про Другу світову війну й українців у ній, а викристалізування всеосяжної та максимально об'єктивної історії власного народу на тлі цього апокаліпсису.

Власне на таких позиціях у Музеї організовано новий експозитарний простір «Україна. Незакінчена війна...», який крізь 
призму мілітарних катаклізмів (від Першої світової війни та періоду визвольних змагань XX ст., головно через Другу світову, екстрапольовано на нинішню російсько-українську війну) сукупно-проблемно та послідовно розповідає про сторічну боротьбу українців за національну суверенність, а також ілюструє реалії існування в умовах бездержав'я впродовж цього часу.

Вдала реалізація такого масштабного задуму, який передбачав насичену проблемно-процесову палітру (до слова, значну увагу сфокусовано на версальській світовій архітектоніці, зокрема стосовно механізмів запуску маховика Другої світової війни, питань національного державного будівництва, процесів оформлення різних моделей української ідентичності як наслідку втрати суверенності, методу та інструментарію асиміляції населення українських теренів цілою низкою окупаційних режимів, іншому, що окреслило місце й роль українства не лише у війні, а й у дальшій світовій, постверсальській, ялтинській геополітичній «кухні») й відповідно значне часове та просторове розширення, потребувала автентики, що до того не була визначальною для музейного зібрання. Тому відкриттю експозиції передувала кількарічна копітка робота з уфондування Музею унікатами, відбувся черговий плідний етап співробітництва музейників із науковими інституціями, архівними установами, дослідниками, колекціонерами, було організовано дискутивні майданчики, низку апробаційних виставкових проектів тощо.

Так, музейне фондове зібрання було цілеспрямовано збагачено артефактами 3 діаспорного середовища - надважливої складової загальної картини, яка дає змогу позбутися переконання, що Червона армія, хоч 7 млн наших співвітчизників у роки Другої світової війни й одягли iii однострої, ні за суттю, ні за формою аж ніяк не виступала національною. Важко уявити той комемораційний хаос, що виник би, якби мільйони українців, які опинилися в німецькій окупації, потенційно стали до служби у Вермахті й у такому разі їхня кількість у складі армій, що ворогували на східноєвропейському театрі війни, була приблизно зіставною. Передусім через свою бездержавність, позбавлене можливості вести боротьбу в лавах власних регулярних збройних сил і відстоювати інтереси своєї країни, розосереджене по всьому світові, українство було представлене як чи не найчисленніший серед шерегу позасуверенних етносів у військах різних країн-учасниць Другої світової війни з обох боків протистояння й під чужими прапорами проливало кров на всіх без винятку полях баталій. При цьому українці переважно не мали у структурі цих армій окремих великих національних мілітарних формацій.

У такому дискурсі осібно постало питання репрезентації автентикою в експозитарному просторі Музею дивізійництва Галичини. Насамперед слід наголосити, що цей самобутній український регіон, який доволі тривалий час перебував у орбіті німецького світу, тісно пов'язаний із ним політично, економічно, культурно, лише за кілька років радянської окупації зазнав докорінного зламу сталого життєустрою своїх мешканців і був занурений у репресивне горнило із сотнями тисяч жертв. Тож, на наш погляд, цілковито усвідомленим видається вибір десятків тисяч галицьких юнаків, які перед обличчям повернення червоної загрози стали до зброї в чорних мундирах (тут можна згадати, яке вбрання в цей самий час носили українці, мобілізовані червоноармійськими «польовими військкоматами»), не кажучи вже про соціально-побутову складову. До того ж людина, яка перебуває у вимірі війни, опиняється в умовах повної руйнації сталих держав- 
них інституцій, законотворчого поля та соціальної системи, існує в епіцентрі концентрованого насилля, повсякчасно робить вимушений моральний вибір. Тож маємо зважувати, де вживати визначення «колаборант».

Завдяки систематичному «польовому» комплектуванню музейної скарбниці на теренах Галичини, Волині, Поділля та інших регіонів кардинально нового звучання в експозиції набув самостійницький резистанс. Акумульований за цей час значний масив особистих матеріалів представників передусім низових ланок теренової та закордонної мережі ОУН, збройних відділів УПА, симпатиків різних самостійницьких таборів, допоміг унаочнити Український визвольний рух як абсолютно сукупне явище, що мало конкретні причини, передумови, обставини та джерела для виникнення й розвитку, гнучку реакцію на всі зміни, постійно еволюціонувало, зрештою, спричинило надзвичайно значущі історичні наслідки. Друга світова війна, логічно, послугувала лише каталізатором для розгортання широкомасштабної боротьби, укладання оптимальної програмної платформи, розробки дієвих стратегії, тактики та методів збройного чину в межах усіх етнічних українських земель, дала змогу набути суб'єктності й вийти на міжнародну арену. Головно крізь призму артефактів, що репрезентує шерег теоретично обгрунтованих та практично оформлених переддержавних і державних національних утворень (Карпатська Україна, національні ради в Києві та Львові, Українська держава 1941 р., повстанські республіки, Українська головна визвольна рада) передано суть українського визвольного руху - здобуття Української соборної самостійної держави.

Окремо музейники в межах підготовки до виставкового проекту напрацювали і зрештою представили в експозиції потужний пласт унікатів, що порушує питання насильної зміни Кремлем етнонаціональної мапи України [1; 9]. Системні депортаційні акції й етноциди, перетворені на одну 3 найбільш дієвих метод укорінення радянського режиму, за розмахом та кількістю задіяного люду зіставні з наймасштабнішими фронтовими операціями, не лише безпосередньо визначають сьогодення нашої держави, а й, на превеликий жаль, нині мають місце для повторення.

Якщо акцентувати власне на матеріалах фондового зібрання як запоруки візуалізації наративу Другої світової війни, то осібне місце в новому експозитарному просторі посіли своєрідні феномени-артефакти із закодованою інформацією про минуле - військові однострої, спорядження, зброя, нагороди, повсякденний одяг, ужиткові речі тощо. Така автентика, представлена у вітринному показі та мистецьких інсталяціях, несе не лише історичний гнозис a й емоційне-філософське навантаження, стає своєрідним комунікативним містком між музеєм та відвідувачем, спонукає до роздумів про власний родинний літопис, викликає бажання через експозицію зробити його суспільним надбанням.

Якщо підсумовувати, то нині Музей не послуговується у висвітленні цього найбільшого й найкривавішого воєнного протистояння в історії людства сталими часовими межами та представленням подієвого полотна, адже такі підходи позбавляють можливості комплексно визначити місце й значення Другої світової війни в історії українства. Науково-творча музейна команда ставить собі за мету розповісти про цей збройний катаклізм проблемно, наблизити відвідувача до його розуміння чи принаймні змусити до аналітики. Своєю чергою насичене багатоманітне музейне зібрання, що нині акумульоване у фондах, яке до того ж 
постійно поповнюється, має забезпечити візуалізацію цих конструктів, а також може послугувати потенційним джерелом для віднайдення такої вкрай потрібної цілісної модерної візії української Другої світової війни.

\section{СПИСОК ВИКОРИСТАНИХ ДЖЕРЕЛ І ЛІТЕРАТУРИ}

1. Вирване коріння: дослідження, документи, свідчення / Національний музей історії України у Другій світовій війні. Меморіальний комплекс, Ін-т історії України НАН України / редкол.: Л.В. Легасова (кер. проекту) та ін. - К., 2020. — 264 с.

2. «За край і волю, за нації долю!»: дослідження, документи, свідчення / Національний музей історії України у Другій світовій війні. Меморіальний комплекс, Ін-т історії України НАН України / редкол.: Л.В. Легасова (кер. проекту) та ін. - К.: Аеростат, 2017. - 324 с.

3. Історія великих страждань. Нацистські табори для радянських військовополонених у м. Славуті на Хмельниччині: дослідження, документи, свідчення / Інститут історії України НАН України; Меморіальний комплекс «Національний музей історії Великої Вітчизняної війни 1941-1945 років». - К.: Аеростат, 2011. — 348 с.

4. Київ очима ворога: дослідження, документи, свідчення / Інститут історії України НАН України; Меморіальний комплекс «Національний музей історії Великої Вітчизняної війни 1941-1945 років». - К., 2012. — 504 с.

5. Київські адреси сповіщень про загибель: дослідження, документи, свідчення / Інститут історії України НАН України; Меморіальний комплекс «Національний музей історії Великої Вітчизняної війни 1941-1945 років». - К.: Аеростат, 2013. - 348 с.

6. Меморіальний комплекс «Національний музей історії Великої Вітчизняної війни 1941-1945 років». Фотоальбом / Меморіальний комплекс «Національний музей історії Великої Вітчизняної війни 1941-1945 років». — К., 2004. — 92 с.

7. Музей. Пам’ять. Пошук [Електронний ресурс]. — Режим доступу: https://martyrology. org.ua. - Назва з екрана.

8. Непрочитані листи 1941-го...: дослідження, документи, свідчення / Інститут історії України НАН України; Меморіальний комплекс «Національний музей історії Великої Вітчизняної війни 1941-1945 років». - К.: Аеростат, 2012. - 504 с.

9. Полиновий травень 44-го: дослідження, документи, свідчення / Національний музей історії України у Другій світовій війні. Меморіальний комплекс, Ін-т історії України НАН України / редкол.: Л.В. Легасова (кер. проекту) та ін. - К., 2017. - 312 с.

10. Смірнова В. Архів С.С. Смирнова у фондозбірні Меморіального комплексу «Національний музей історії Великої Вітчизняної війни 1941-1945 років»: радянські військовополонені на окупованій території України (джерелознавчий аспект) / В. Смірнова // Військово-історичний меридіан. Електронний науковий журнал. - Вип. 1 (3) / Меморіальний комплекс «Національний музей історії Великої Вітчизняної війни 1941-1945 років», Ін-т історії України НАН України. - К., 2014. - С. 73-94. [Електронний ресурс]. - Режим доступу: https://vim.gov.ua/pages/_journal_files/10.10.2014/pdf/73-94.pdf. — Назва з екрана.

11. Смірнова В. Український визвольний рух: джерелознавчий зріз музейної колекції / В. Смірнова, О. Білоус // «За край і волю, за нації долю!»: дослідження, документи, свідчення / Національний музей історії України у Другій світовій війні. Меморіальний комп- 
лекс, Ін-т історії України НАН України / редкол.: Л.В. Легасова (кер. проекту) та ін. - К.: Аеростат, 2017. - С. 66-97.

12. Смірнова В. Колекція документів з архіву члена ОУН А. Михалевича: перші результати історико-археографічного опрацювання / В. Смірнова // 3 архівів ВУЧК - ГПУ НКВД - КГБ. - 2011. - Вип. 2. - С. 266-291.

13. «...То була неволя». Спогади та листи остарбайтерів / Інститут історії України НАН України, Меморіальний комплекс «Національний музей історії Великої Вітчизняної війни 1941-1945 років». - К., 2006. - 544 с.

14. Українські в’язні концтабору Маутгаузен: Свідчення тих, хто вижив / Інститут істоpiї України НАН України, Меморіальний комплекс «Національний музей історії Великої Вітчизняної війни 1941-1945 років», Український інститут національної пам'яті. - К., 2009. - 336 c.

15. Шевченко М. Колекція персональних матеріалів учасників радянського руху Опору в Україні: джерелознавчий огляд / М. Шевченко, В. Смірнова // Партизанські колекції Меморіального комплексу «Національний музей історії Великої Вітчизняної війни 19411945 років». Особові фонди. Путівник / Інститут історії України НАН України; Меморіальний комплекс «Національний музей історії Великої Вітчизняної війни 1941-1945 років». — К.: Аеростат, 2014. - С. 10-32.

\section{REFERENCES}

1. Vyrvane korinnya: doslidzhennya, dokumenty, svidchennya / Nacional'nyj muzej istoriyi Ukrayiny u Druhij svitovij vijni. Memorial'nyj kompleks, In-t istoriyi Ukrayiny NAN Ukrayiny / redkol.: L.V. Legasova (ker. proektu) ta in. — K., 2020. — 264 s.

2. «Za kraj i volyu, za naciyi dolyu!»: doslidzhennya, dokumenty, svidchennya / Nacional'nyj muzej istoriyi Ukrayiny u Druhij svitovij vijni. Memorial'nyj kompleks, In-t istoriyi Ukrayiny NAN Ukrayiny / redkol.: L.V. Legasova (ker. proektu) ta in. — K.: Aerostat, 2017. — $324 \mathrm{~s}$.

3. Istoriya velykykh strazhdan'. Nacysts'ki tabory dlya radyans'kykh vijs'kovopolonenykh u m. Slavuti na Khmel'nychchyni: doslidzhennya, dokumenty, svidchennya / Instytut istoriyi Ukrayiny NAN Ukrayiny; Memorial'nyj kompleks «Nacional'nyj muzej istoriyi Velykoyi Vitchyznyanoyi vijny 1941-1945 rokiv». - K.: Aerostat, 2011. - 348 s.

4. Kyyiv ochyma voroha: doslidzhennya, dokumenty, svidchennya / Instytut istoriyi Ukrayiny NAN Ukrayiny; Memorial'nyj kompleks «Nacional'nyj muzej istoriyi Velykoyi Vitchyznyanoyi vijny 1941-1945 rokiv». - K., 2012. - 504 s.

5. Kyyivs'ki adresy spovishchen' pro zahybel': doslidzhennya, dokumenty, svidchennya / Instytut istoriyi Ukrayiny NAN Ukrayiny; Memorial'nyj kompleks «Nacional'nyj muzej istoriyi Velykoyi Vitchyznyanoyi vijny 1941-1945 rokiv». — K.: Aerostat, 2013. — 348 s.

6. Memorial'nyj kompleks «Nacional'nyj muzej istoriyi Velykoyi Vitchyznyanoyi vijny 1941-1945 rokiv». Fotoal'bom / Memorial'nyj kompleks «Nacional'nyj muzej istoriyi Velykoyi Vitchyznyanoyi vijny 1941-1945 rokiv». — K., 2004. — $92 \mathrm{s.}$

7. Muzej. Pamyat'. Poshuk [Elektronnyj resurs]. — Rezhym dostupu: https://martyrology.org. ua. - Nazva z ekrana. 
8. Neprochytani lysty 1941-go...: doslidzhennya, dokumenty, svidchennya / Instytut istoriyi Ukrayiny NAN Ukrayiny; Memorial'nyj kompleks «Nacional'nyj muzej istoriyi Velykoyi Vitchyznyanoyi vijny 1941-1945 rokiv». - K.: Aerostat, 2012. — 504 s.

9. Polynovyj traven' 44-ho: doslidzhennya, dokumenty, svidchennya / Nacional'nyj muzej istoriyi Ukrayiny u Druhij svitovij vijni. Memorial'nyj kompleks, In-t istoriyi Ukrayiny NAN Ukrayiny / redkol.: L.V. Legasova (ker. proektu) ta in. - K., 2017. — 312 s.

10. Smirnova V. Arkhiv S.S. Smyrnova u fondozbirni Memorial'noho kompleksu «Nacional'nyj muzej istoriyi Velykoyi Vitchyznyanoyi vijny 1941-1945 rokiv»: radyans'ki vijs'kovopoloneni na okupovanij terytoriyi Ukrayiny (dzhereloznavchyj aspekt) / V. Smirnova // Vijs'kovo-istorychnyj merydian. Elektronnyj naukovyj zhurnal. - Vyp. 1 (3) / Memorial'nyj kompleks «Nacional'nyj muzej istoriyi Velykoyi Vitchyznyanoyi vijny 1941-1945 rokiv», In-t istoriyi Ukrayiny NAN Ukrayiny. - K., 2014. - S. 73-94 [Elektronnyj resurs]. — Rezhym dostupu: https://vim.gov.ua/ pages/_journal_files/10.10.2014/pdf/73-94.pdf. — Nazva z ekrana.

11. Smirnova V. Ukrayins'kyj vyzvol'nyj rukh: dzhereloznavchyj zriz muzejnoyi kolekciyi / V. Smirnova, O. Bilous // «Za kraj i volyu, za naciyi dolyu!»: doslidzhennya, dokumenty, svidchennya / Nacional'nyj muzej istoriyi Ukrayiny u Druhij svitovij vijni. Memorial'nyj kompleks, In-t istoriyi Ukrayiny NAN Ukrayiny / redkol.: L.V. Legasova (ker. proektu) ta in. - K.: Aerostat, 2017. - S. 66-97.

12. Smirnova V. Kolekciya dokumentiv z arkhivu chlena OUN A. Mykhalevycha: pershi rezul'taty istoryko-arkheohrafichnoho opracyuvannya / V. Smirnova // Z arkhiviv VUChK GPU - NKVD - KGB. - 2011. - Vyp. 2. - S. 266-291.

13. «...To bula nevolya». Spohady ta lysty ostarbajteriv / Instytut istoriyi Ukrayiny NAN Ukrayiny, Memorial'nyj kompleks «Nacional'nyj muzej istoriyi Velykoyi Vitchyznyanoyi vijny 1941-1945 rokiv». — K., 2006. - 544 s.

14. Ukrayins'ki vyazni konctaboru Mauthauzen: Svidchennya tykh, khto vyzhyv / Instytut istoriyi Ukrayiny NAN Ukrayiny, Memorial'nyj kompleks «Nacional'nyj muzej istoriyi Velykoyi Vitchyznyanoyi vijny 1941-1945 rokiv», Ukrayins'kyj instytut nacionalnoyi pamyati. — K., 2009. - $336 \mathrm{~s}$.

15. Shevchenko M. Kolekciya personal'nykh materialiv uchasnykiv radyans'koho rukhu oporu v Ukrayini: dzhereloznavchyj ohlyad / M. Shevchenko, V. Smirnova // Partyzans'ki kolekciyi Memorial'noho kompleksu «Nacional'nyj muzej istoriyi Velykoyi Vitchyznyanoyi vijny 19411945 rokiv». Osobovi fondy. Putivnyk / Instytut istoriyi Ukrayiny NAN Ukrayiny; Memorial'nyj kompleks «Nacional'nyj muzej istoriyi Velykoyi Vitchyznyanoyi vijny 1941-1945 rokiv». — K.: Aerostat, 2014. - S. 10-32. 
Yankovenko O.O. , head curator of the National Museum of the History of Ukraine in the Second World War. Memorial complex (Kyiv, Ukraine)

ORCID: https://orcid.org/0000-0002-7372-8903

Tretiak V.L. , Candidate of Historical Sciences, head of sector of scientific and fund work of the National Museum of the History of Ukraine in the Second World War. Memorial complex (Kyiv, Ukraine)

ORCID: https://orcid.org/0000-0002-4324-4545

\section{THE STOCK COLLECTION AS A GUARANTEE THE VISUALISATION OF THE NARRATIVE OF THE SECOND WORLD WAR (as example - the National Museum of the History of Ukraine in the Second World War. Memorial complex)}

Now it is urgent for Ukrainians to create a complete and maximally objective model of national history in order to determine their own civilizational future. Special attention should be paid to problems that cause resonance and contradictions in society and traumatize it. First of all, this concerns the issue of the Second world war. It has generated a large number of memorable structures among Ukrainians, which significantly affects the current processes in the state. The relevant institutions, that accumulate intellectual and methodological narratives, are called upon to find, adapt and integrate such a vision into society. A separate mission, belongs to Museum institutions, that not only carry out research, but also visualize them to the wide public.

The article considers the stock collection of the National Museum of the history of Ukraine in the Second world war. Memorial complex, the history of its formation and development. First, it is used to analyze the experience of visualization of a number of leading information models at various stages of historical science formation in Ukraine: from the Soviet era, after the restoration of independence and during the Russian-Ukrainian war. Thanks accumulating collection, as well as permanent, susceptible to demands of the time filling the Museum's treasure house of authentic artifacts, gradually organized space, deepens knowledge and approaches to understanding World war II, and the Memorial allows you to transform from a Soviet propaganda to Ukrainian commemorative dimension. Secondly, the collection is a powerful springboard for further study of this largest armed conflict in the history of mankind.

The Fund collection, its constant acquisition, was useful for scientists and museum workers in finding modern theoretical structures of the Second world war, and also provided: the creation of urgent expositions and exhibition projects; the introduction of new source layers into wide circulation; the publication of scientific, popular science, scientific and methodological works; the introduction of large-scale socio-humanitarian projects.

Experience shows that the creation of a complete, maximally objective historical model, as well as its visualization by Museum institutions, requires a departure from chronological and eventbased discourse and its translation primarily into a problematic plane.

Keywords: National Museum of the history of Ukraine in World war II. Memorial complex, stock collection, exposition, source, visualization, World war II, Ukraine. 